\title{
An Autosegmental Analysis of Tone Usage Among Yoruba-Speaking CVA-Aphasic Adults
}

\author{
Mercy Oluwaseyi Agbeye ${ }^{1}$, Humphrey Muyambango Kapau ${ }^{2}$
}

\author{
${ }^{1}$ University of Ibadan \\ Oduduwa Road, 200132, Ibadan, Nigerian \\ ${ }^{2}$ University of the Western Cape \\ Robert Sobukwe Road, Bellville 7535, Republic of South Africa
}

DOI: $10.22178 /$ pos.74-12

LCC Subject Category:

PE1001-1693

Received 21.08.2021

Accepted 25.09.2021

Published online 30.09.2021

Corresponding Author:

Mercy Oluwaseyi Agbeye

mercyagbeye74@gmail.com

(C) 2021 The Authors. This

article is licensed under a

Creative Commons Attribution

4.0 License @) (1)

\begin{abstract}
This inquiry investigated tone use among Yoruba-speaking adults recovering from an aphasic insult/attack initiated by a cerebral vascular accident (CVA), otherwise known as a stroke. In pursuing the aim of the study, the research was guided by three research questions, namely, do Yoruba-speaking aphasic adults have the perceptual ability to perceive tone in the language; can Yorubaspeaking aphasic adults differentiate between the three lexical tones in the language; and which of lexical tones do Yoruba speaking aphasic adults find difficult to perceive? The study drew upon the theoretical and analytical scope of the autosegmental approach and a constructivist methodology paradigm inspired by a descriptive research design that used the qualitative approach. Data elicited from purposively sampled informants via structured interviews involving two groups of participants three aphasic Yoruba individuals and three Yoruba non-aphasic individuals in Nigeria. The purposive sampling was premised on informants' dialectal proficiency, availability and diversity, and occurrence of CVA (stroke). The aphasic subjects were identified with the initials $A B, C D$ and $E F$ to conform to confidentiality etiquette in clinical linguistics. For ethical consideration, the informants were required to fill in a consent form before eliciting data from them. Once that was done, the aphasics were availed 100 words from the combined Swadesh 200 and Ibadan $\mathbf{4 0 0}$ wordlist of essential and cultural items, recorded by the non-aphasic individuals who speak Yoruba as their first language, to identify which tones they perceive. The data elicited was analysed using the perceptual approach in which the recorded data was listened to several times to discover if adult Yoruba speakers that are aphasic were still able to recognise the high ("), mid () and low tone ( ) in words. The findings reviewed that Yoruba aphasics have diverse perceptual abilities of tone.

Furthermore, it was established that Yoruba aphasics displayed varying deficiencies in differentiating the three lexical tones of Yoruba. Of the three lexical tones $(\mathrm{H}, \mathrm{M}$ and $L$ ), the unmarked $M$ tone was consistent, while the $H$ and $L$ tones had varying perceptual outcomes among the CVA-aphasics. The implication of the finding is that tone recoveries among CVA-aphasics is never the same and, therefore, calls for various linguistic therapies according to each CVA-aphasic case.
\end{abstract}

Keywords: tone, aphasia, autosegmental analysis, cerebral vascular accident (CVA), Yoruba.

\section{INTRODUCTION}

From time immemorial, language has proven to be at the centre of human existence. It is the conduit of ideas by which humans have been able to initiate, sustain and sometimes destroy their dayto-day undertakings both in the private and public domains. Essentially, at the centre of language is the desire to perform many functions, such as the need to non-instinctively communicate ideas, emotions and desires using voluntarily produced symbols; attaining cooperation through the use of arbitrary vocal symbols; interaction through, among others, habitually used oral-auditory arbitrary symbols; and infinite communication based on a finite set of rules. From the aforementioned perceived functions and nature of language, 
linguists understand that language need not be articulated (i.e., need not be produced by organs of speech) because language can also be made of signs and movements.

Human language is expressed through spoken language, otherwise known as spoken language or simply speech [7]. Through speech, humans transmit their emotions, ideas and other intentions to co-interlocutors in everyday life. However, it is known that humans experience some language disorders associated with spoken language that are triggered by different variables. For example, some language disorders are triggered by premature birth; low birth weight; loss of hearing; autism; Fragile X syndrome (a genetic condition causing intellectual disability); Down syndrome (a genetic chromosome 21 disorder linked to developmental and intellectual delays); cerebral vascular accident (i.e. a 'stroke' in a layman's language); poor nutrition; brain injury; and cerebral palsy (a disorder of movement, muscle tone or posture due to abnormal brain development, often before birth). All these disorders will have a varying degree of language impairment on different aspects of language [20].

Additionally, some language disorders are initiated by an insult (i.e., an attack) to the brain areas responsible for the perception of human language (Wernicke's area) or those responsible for the production of human language (Broca's area). Such damages may happen on the brain's surface (cortical regions) or underneath it (subcortical regions), resulting in various linguistic inabilities in an individual. Aphasia is the complete or partial loss of language abilities resulting from damage to the cortical and/or subcortical brain tissue. In contrast, the study of such language losses is referred to as aphasiology [18]. Thus, aphasia is not a disease but a symptom of brain damage. For this, neurologists (people who study the brain) refer to aphasia as a neurological disorder caused to some part of the brain. Causes of aphasia are many, but the commonest one is a Cerebral Vascular Accident (CVA), commonly known as a stroke [7]. From way back, aphasia as a neurological speech disorder has attracted diverse linguistic research mainly spread across the research angles of causes, symptoms and therapies for the different types of aphasia $[10,19,21,23]$. This article looks at how Yoruba-speaking aphasic patients use tone after suffering an aphasic insult (i.e., aphasic attack) that leaves some neurological lesion (i.e., neurological damage) to their brain. It is essential to provide some salient geo-linguistic information about the Yoruba language.

As Figure 1 below indicates, Yoruba is a Bantu language spoken in the Southwestern part of Nigeria, West Africa. The country spans a total surface area of 923769 square kilometres and, based on the projection of the latest United Nations data (2021), the nation has a population of $212,006,180$. Nigeria's neighbours are Niger, Chad, Cameroon and Benin.

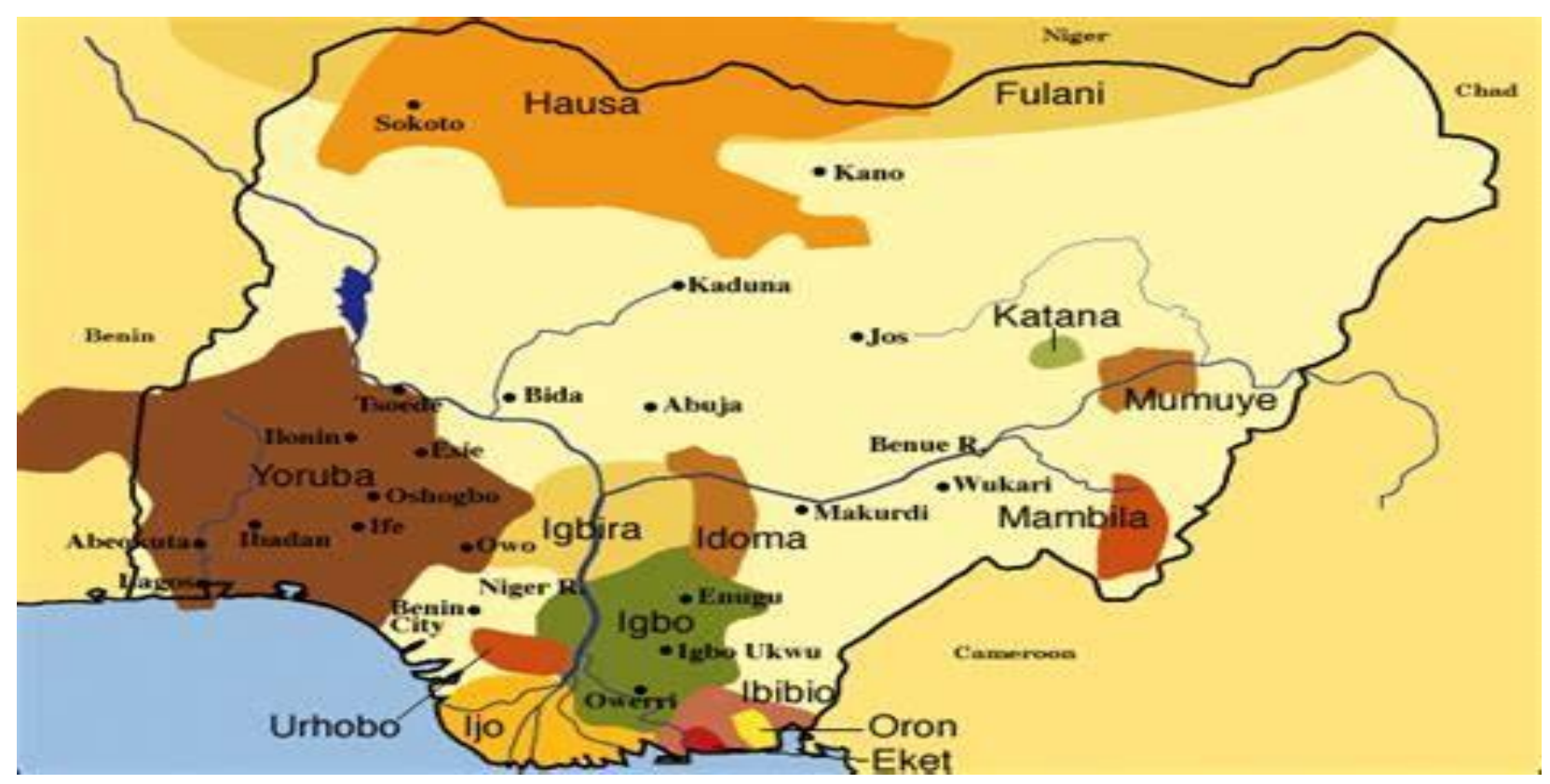

Figure 1 - Geographical concentration of Yoruba language in Nigeria 
Apart from its geographical concentration indicated in Figure 1, Yoruba is also spoken in African countries like the Republic of Benin, Togo, Ghana, Cote D'Ivoire, Sudan and Sierra Leone. Furthermore, according to [1], the geo-linguistic distribution of Yoruba also spreads to Haiti, Caribbean Island, Trinidad and Tobago, among others.

Author [8] notes that Yoruba belongs to the Kwa sub-group of the Niger-Kordofanian Phylum of African languages in terms of its linguistic classification. This confirms [10] classification of African languages, which classifies Yoruba as a Bantu language belonging to the Kwa group of the NigerCongo branch of the Congo-Kordofanian Family. On the African continent, the language has over 50-million speakers that include a dialectal area spanning Benin, Togo, with smaller migrated communities in Cote D'Ivoire, Sierra Leone and The Gambia. Yoruba phonology posits three types of tone: high $(\mathrm{H})$ tone $(')$, mid $(\mathrm{M})$ tone ${ }^{-}$) and low (L) tone ( ). The mid-tone is unmarked in Yorùbá orthography. A way of viewing the three-level tones in Yoruba is to think of the music note they correspond to, as shown in (1) below.

$\begin{array}{ll}\text { Tone } & \text { musical note correlation } \\ \mathrm{H} & \text { (mi) } \\ \mathrm{M} & \text { (re) } \\ \mathrm{L} & \text { (do) }\end{array}$

As (1) shows, the L tone is the lowest at (do), while the $\mathrm{H}$ tone is the highest at (mi). In-between is the $\mathrm{M}$ tone at (re). Moving from $\mathrm{L}$ to $\mathrm{H}$ tone is upward graduation (crescendo), while from $\mathrm{H}$ tone to $\mathrm{L}$ tone is downward in nature (decrescendo). Tone marks in Yoruba are significant because they help distinguish between similar spelling words but differ in meaning. This is shown in (2) below:

Ilá (re mi) $\quad$ "okra"
Ilà (re do)

In (2), it can be seen that the two words are distinguished by the $\mathrm{H}$ tone and the $\mathrm{L}$ tone. This shows that 'Ilá' (okra) and 'Ilà' (mark) are minimal pairs.

The current undertaking conducts an autosegmental analysis of tone usage among Yoruba-speaking aphasic adults. The study arises from a review of related literature highlighting that although many studies have looked at aphasia, there have never been substantial studies in clinical linguistics that have explored neurological-related speech disorders among aphasic patients who speak some African languages. Because of those knowledge gaps above, this article investigates whether tonological processes triggered by certain lexical items present in the speech of Yoruba non-aphasic patients is evident in that of Yoruba aphasic patients.

Statement of the problem. Several studies have addressed different aspects of aphasia among people who have had an aphasic insult. Notable among these are [2], who explored the role of inflectional morphology in agrammatism; [23], who conducted a phonological analysis in the speech of Nigerian bilingual adults and [16], who examined the pronominal production resumption, focus constructions (who-questions) and focused declarative in Akan. However, despite studies conducted on grammar aspects of aphasic patients [2] and those that have looked at some African languages in Nigeria, no study has explored the tone of aphasic patients in Yoruba language. Additionally, although some studies undertook a phonological analysis in the speech of Nigerian bilingual adults [23], no study has concentrated on tone as a suprasegmental phoneme in Yoruba concerning Yoruba-speaking aphasic adults. This is the knowledge gap that this article explored. Therefore, the statement of the problem, put in question form, was: what are the aspects of tone usage among Yoruba-speaking aphasic patients?

Research questions. The current study was guided by the following research questions: 1) Do Yoruba-speaking aphasic adults have the perceptual ability to perceive tones in the language? 2) Can Yoruba-speaking aphasic adults differentiate between the three lexical tones in the language? 3) Which lexical tones does Yoruba speaking aphasic adults find difficult to perceive?

\section{Literature review}

As a neurological speech disorder, aphasia has attracted research by many linguists, especially in phonology, morphology, syntax, and semantics. This section of the article commits itself to review related literature around the statement of the problem related to aphasia.

The first notable study is that of [2], who justified the role of inflectional morphology in agrammatism. In their study, [2] selected three Germanspeaking agrammatic with a left hemisphere 
lesion due to cardiovascular accidents as subjects in justifying the role of inflectional morphology. The agrammatic were addressed with the initials $\mathrm{CB}, \mathrm{MH}, \mathrm{HR}$ ). The areas of morphology investigated by [2] were gender, number and case. In their methodological and theoretical approach to the study, [2] justified the use of Lexical Morphological Theories (LMT) against Split Morphological Theories (SMT) as a linguistic framework to account for data for agrammatic patients $[13,15]$. Authors [2] proved that the German aphasic patients studied demonstrated good command in the inflected forms of morphology. This study was similar to and different from that of [2] on three primary grounds. First, like authors [2], this study explored some of the linguistic manifestations associated with aphasic patients. Such an undertaking provides additional materials of related literature on the subject. However, while [2] looked at the morphology in grammatical sampled from agrammatic, this inquiry looked at tone use among Yoruba-speaking aphasics. Thirdly, by looking at Yoruba-speaking aphasics and not German-speaking ones, this research provided an additional dimension to studies on aphasia by looking at Yoruba - a language found in the CongoKordofanian language family - and not German, an Indo-European family language. Such a diverse choice in language family provided a remarkable shift in the subject of study and opened an avenue for comparative studies among aphasics in future studies.

The author [23] carried out a phonological analysis in the speech of 10 bilingual Nigerian adults with Wernicke's aphasia. Drawn from ten Wernicke aphasic adults as part of methodology sample size, and the optimality theory (OT) as his theoretical framework, [23] observed that certain phonological processes surface in the speech of Wernicke aphasic adults. The observed phonological processes were substitution, deletion and epenthesis, all of which affected consonants than vowels. In deletion, [23] observed m-deletion (e.g., 'problem' > 'proble'); d-deletion (e.g., 'proud' $>$ 'prou'); and l-deletion (e.g., 'calendar' > 'caendar'). Substitution included the ' $w$ ' for ' $t$ ' substitution (e.g., 'teach' > 'weach' manifesting substitution of ' $w$ ' for ' $t$ '; and 'yesterday' > festerday' in which ' $\mathrm{f}$ ' is substituted for ' $y$ '). In epenthesis, the aphasic patients displayed n-insertion (e.g., 'fee' > 'feen'; and 'stole' > 'stonle'); and u-insertion (e.g., 'fifty' > 'fifuty'). The current undertaking was similar to [23] only based on both of them focusing on aphasia in Nigerian adults. However, the difference between the two is that while [23] explored the phonological aspects of Wernicke aphasics from the angle of phonological processes, this enquiry looked at the tone. A shift in focus from phonological processes to tone offered additional knowledge to the existing literature on Nigerian aphasics.

Authors [12] examined the function that direct and indirect speech plays in discourse comprehension. To back up their findings, they compared English and Dutch speaking individuals with and without aphasia. They analysed by developing an English version of the Dutch iPad-based Direct Speech Comprehension (DISCO) test. At the end of their research, they discovered that participants without aphasia performed better than those with aphasia; English speaking participants involved performed worse than Dutch participants, and direct speech contained in narratives were easier to understand than indirect speech. The current study differs from that of [12] based on it looking at the tone of aphasics. In this regard, it added more knowledge to that of [12].

Another notable study of [22] carried out a time reference analysis in Thai speakers with agrammatic aphasia. The analysis aimed to investigate if referring to the past, present, and future was possible among individuals with agrammatic aphasia. 23 Thai speakers participated in the research; 15 were agrammatic, while 18 were non-agrammatic. The research took production and auditory approach. The investigation results revealed that non-agrammatic Thai speakers had no difficulty with the past, present and future production and comprehension. However, agrammatic Thai speakers experienced difficulty in conditions that entails reference to the future. But in production, Thai speakers with agrammatism replaced the future time reference with negation. According to [23], the use of negation by the agrammatic Thai speakers might be because it helps to reduce their processing load. This study is similar to that of [23] based on being aphasia-related. However, while [23] looked at aspects of agrammatism in terms of tense, this study explored tone among Yoruba-speaking adults. In this regard, it was unique.

Lastly, [16] research stems from the premise that the linguistic phenomenon of resumption is understudied in agrammatism. To account for this, they carried out an analysis to examine the production of (pronominal) resumption, focus constructions (who-questions). They focused on 
declarative in Akan (a tonal language spoken in Ghana and parts of Cote D'Ivoire). The research presented two groups of participants, five with left hemisphere brain-damaged suffering from agrammatic aphasia and ten non-brain-damaged speakers. Authors [16] investigation led to the following two key findings in Akan: firstly, linguistic tones and resumptive pronouns, as well as clause determiners, were intact in Akan agrammatic speakers; and secondly, that production of declarative sentences in derived word order was impaired, but wh-object questions were relatively well-preserved by Akan agrammatic speakers. Though equally centred around aphasia on one of the African languages, this research did not look at the linguistic phenomenon of resumption in agrammatism but on the tone from an autosegmental analysis perspective. The difference in African language (from [16] in this study) provided a broadened platform of related literature on aphasia vis-à-vis African languages.

\section{Theoretical and conceptual frameworks}

Autosegmental approach. This enquiry employed the autosegmental approach to capture tonological aspects of Yoruba words. First proposed by [10], the autosegmental approach to phonology posits that the relationship among phonological units must be arranged in hierarchical nature known as tiers for easy identification. Unlike previous approaches to phonology like generative phonology that linearly presented phonological phenomenon, the autosegmental approach addresses challenges associated especially with tonal representation by doing so in a multi-tiered and not the linear string of segments. The author [24] notes that [10] proposes an autonomous tone representation from the rest of the segments. Regular segments such as consonants and vowels are represented at one level, and tone is above them, joined by association lines to link the two tiers. "For instance, the syllable, the stress, the phonological processes, and the distinctive features are organised in a well-established internal hierarchical order" [24].

Within the autosegmental approach, the study used the perceptual approach to analyse tone among Yoruba-speaking aphasic patients.

Understanding aphasia. To help the reader best appreciate the discussions of the findings presented in this enquiry, we must provide more details about aphasia. Although aphasia is widely used as an umbrella term to mean either partial loss or complete loss of language as a result of damage to parts of the brain responsible for language, some literature distinguishes between partial language loss and complete language loss by calling the former dysphasia and the latter aphasia [7]. In this article, we used 'aphasia' to mean language loss, regardless of whether it is a partial or complete loss, as a result of damage to the part of the brain responsible for language. It is also worth noting that aphasia is not a disease but a symptom of brain damage. For this, neurologists refer to aphasia as a neurological disorder caused to some part of the brain. Causes of aphasia are many, but the commonest one is a Cerebrovascular Accident (CVA), popularly known as a stroke.

There are many types of aphasia, and they derive their name from the type of criterion used in classifying them, hence interlinked. Depending on the criteria used, aphasia can be viewed as temporal or permanent aphasia; receptive or expressive aphasia; Broca's, Wernicke's or global aphasia; and so forth. We shall now discuss the aforementioned different types of aphasia.

Temporal and permanent aphasia. Temporal and permanent aphasia are classified based on during aphasic insult (i.e., aphasic attack). Temporal aphasia lasts for a few hours or even a few days. Persons showing signs of temporal/transient aphasia recover within a few days. Suppose they do not do so within a few days, in that case, most transient aphasics will recover within three months, after which complete recovery is unlikely as permanent aphasia (as the name implies) would have kicked in by then $[7,18]$.

Expressive and receptive aphasia. Clinical linguists distinguish between expressive and receptive aphasia using the criterion of what aspects of language are affected by an aphasic insult. Expressive aphasia applies to people who have problems in expressing themselves in speech (speaking and writing). For example, the person may know what they intend to communicate but may not find words to use. In other words, they have fluency problems. Because of this, expressive aphasia is also called non-fluent aphasia.

In receptive aphasia, the patient is fluent but has problems understanding language.

Broca's, Wernicke's and global aphasia. The third alternative criterion used in classifying aphasia is looking at the brain areas affected by aphasia. This is the most widely used criterion, and it typically 
classifies the types of aphasia into Broca's aphasia, Wernicke's aphasia, and global aphasia.

Broca's aphasics may understand speech, but their ability to produce language is greatly affected, whether in writing or speech. Broca's aphasia usually happens when the part of our brain called the Broca's area (responsible for language production) is damaged [7]. In most cases, injury to the interior frontal gyrus and the linguistic areas of the motor cortex, which is the frontal lobe where the Broca's area is situated, usually results in Broca's aphasia. For example, suppose a person with Broca's aphasia has limitations in the ability to produce writing. It is said that he has a form of Broca's aphasia called agraphia (i.e., inability to write). There are also people with Broca's aphasia who can write but just cannot write coherently. Such is said to have a type of Broca's aphasia known as dysgraphia (i.e., inability to write coherently). On the other hand, persons with Broca's aphasia who display difficulties in speaking are said to have a variant of Broca's aphasia called dysphasia (i.e., inability to speak coherently). When it comes to reading, complete inability to read in Broca's aphasics (i.e., people with Broca's aphasia) are called alexia, and partial inability to read due to Broca's aphasia is classified as dyslexia.

Unlike Broca's aphasia, Wernicke's aphasia is caused by injury to the brain's temporal lobe where the Wernicke's area (an area in our brains primarily responsible for language processing) is located. People having Wernicke's aphasia have a problem of retrieving words from their memory and tend to define or describe something instead of mentioning it (e.g., they would say "something you sit on' instead of simply mentioning "chair"). They also exhibit problems in using determiners (e.g., "the") and pronouns (e.g., "he/she"). Coming this far, you would notice that Broca's aphasia corresponds to expressive aphasia while Wernicke's aphasia is the same as receptive aphasia above. The only difference is the criterion used in naming.

The third type of aphasia under the third alternative criterion of classifying aphasia is global aphasia. Global aphasia gets its name from its severity scale on the patient as language impairment involves both Broca's and Wernicke's areas. Survivors with global aphasia cannot understand speech or speak, although some global aphasics can still communicate using written language $[19$, $23,24,25,26]$.
Some other types of aphasia termed based on regions of the brain affected include conduction aphasia (a type of aphasia in which the aphasic displays fluent speech output but has severely impaired repetition abilities as a result of interferences in cortical pathways between the Broca's area and the Wernicke's area); transcortical motor aphasia (whereby a person can repeat things easily but are not fluent because of impaired connection between the Broca's areas and its surrounding frontal lobe association areas); and transcortical sensory aphasia where an individual displays compulsive repetitions, otherwise known as echolalia in clinical linguistics $[7,18]$.

This article focused on tone usage among Yorubaspeaking aphasic adults from the perspective of autosegmental analysis.

\section{METHODOLOGY}

Due to research questions that sought to establish reality and knowledge descriptively, the present study was framed within the ontological and epistemological frontiers of the constructivist paradigm. As opposed to the positivist paradigm, which views reality and knowledge in terms of quantitative terms, the major postulation of constructivism is the idea that reality and knowledge can be attained non-quantitatively as long as the data collection and analysis is, firstly, systematic and transparent and, secondly, the interpretation is derived directly from the data being observed $[9,17]$. Within the constructivist paradigm is a descriptive research design because such a design essentially answers the questions 'what', 'who', where', when' and 'how' by using descriptions [4, $6,14]$.

The qualitative approach was used in the descriptive research design. Data were elicited from informants via structured interviews involving two participants, notably three aphasic Yoruba individuals and three Yoruba non-aphasic individuals in Nigeria. The informants were selected via purposive sampling based on their dialectal proficiency, availability and diversity, and cerebral vascular accident (CVA), commonly referred to as a stroke. The aphasic subjects were identified with the initials $\mathrm{AB}, \mathrm{CD}$ and $\mathrm{EF}$ to conform to confidentiality etiquette in clinical linguistics [2].

Before the elicitation of data from informants, the informants were required to fill a consent form. A hundred words were picked randomly from the combined Swadesh 200 and Ibadan 400 wordlist of essential and cultural items (i.e., the Ibadan 500 
wordlist). The aphasic individuals were given a tape of 100 Yoruba words, recorded by the nonaphasic individuals who speak Yoruba as their first language, to identify which tones they perceive. The data elicited was analysed using the perceptual approach in which the recorded data was listened to several times to discover if adult Yoruba speakers that are aphasic were still able to recognise the high ('), mid ( $\left.{ }^{-}\right)$and low tone ( ) in words, henceforth the $\mathrm{H}, \mathrm{M}$ and $\mathrm{L}$ tones respectively.

\section{RESULTS AND DISCUSSION}

The study established that aphasics $\mathrm{AB}, \mathrm{CD}$ and $\mathrm{EF}$ displayed varying perceptions of tone in some selected words that made up the combined Swadesh 200 and Ibadan 400 wordlist of essential and cultural items. The findings are presented in Table 1 below.

Table 1 - Merged Swadesh 200 and Ibadan 400 wordlist of essential and cultural items

\begin{tabular}{|c|c|c|c|c|c|c|}
\hline $\mathrm{S} / \mathrm{N}$ & English word & $\begin{array}{c}\text { Yoruba } \\
\text { translation }\end{array}$ & Tone & $\begin{array}{l}\text { A.B tone } \\
\text { perceived }\end{array}$ & $\begin{array}{c}\text { C.D tone } \\
\text { perceived }\end{array}$ & $\begin{array}{c}\text { E.F tone } \\
\text { perceived }\end{array}$ \\
\hline 1 & Snail & Ìgbín & $\mathrm{LH}$ & $\mathrm{LM} / \mathrm{M}$ & L H & L M H \\
\hline 2 & Carry & Gbé & $\mathrm{H}$ & $\mathrm{M} / \mathrm{L}$ & L L & $\mathrm{H}$ \\
\hline 3 & Stand & Dìde & L M & $\mathrm{M} / \mathrm{L}$ & $\mathrm{H} \mathrm{L}$ & L M \\
\hline 4 & Beard & Irun àgbọ̀n & M M L L & $\mathrm{L} \mathrm{M}$ & L H H H & L M M L \\
\hline 5 & Friend & Òré & $\mathrm{LH}$ & $\mathrm{M}$ & $\mathrm{L} \mathrm{H}$ & $\mathrm{LH}$ \\
\hline 6 & Buy & Rà & $\mathrm{L}$ & $\mathrm{L}$ & $\mathrm{H} \mathrm{H}$ & $\mathrm{L}$ \\
\hline 7 & Disappear & Parẹ́ & M H & $\mathrm{M}$ & $\mathrm{H} \mathrm{H}$ & $\mathrm{M} \mathrm{H}$ \\
\hline 8 & Farm & Oko & M M & $\mathrm{M} / \mathrm{L}$ & $\mathrm{H} \mathrm{H}$ & M M \\
\hline 9 & Vehicle & Ọkọ̀ & $\mathrm{ML}$ & $\mathrm{L}$ & $\mathrm{LH}$ & $\mathrm{ML}$ \\
\hline 10 & Penis & Okón & M H & $\mathrm{M}$ & $\mathrm{LH}$ & M H \\
\hline 11 & Syllable & Sílábù & H H L & LM & $\mathrm{H} \mathrm{H}$ & H H L \\
\hline 12 & Rat & Eku & M M & $\mathrm{M}$ & L H & Unanswered \\
\hline 13 & Bolanle & Bóláńlé & $\mathrm{H} \mathrm{H} \mathrm{H} \mathrm{H}$ & LM & $\mathrm{LH} \mathrm{H}$ & Unanswered \\
\hline 14 & Hunter & Ọdẹ & M M & M & $\mathrm{L} \mathrm{H}$ & Unanswered \\
\hline 15 & Fool & Ọdẹ̀ & L L & $\mathrm{L}$ & $\mathrm{H} \mathrm{H}$ & Unanswered \\
\hline 16 & Describe & Șàlàyé & L L H & $\mathrm{LM} / \mathrm{M}$ & $\mathrm{H} \mathrm{H} \mathrm{H}$ & M M H \\
\hline 17 & Yoruba & Yorùbá & M L H & L M & $\mathrm{H} \mathrm{H} \mathrm{H}$ & M M H \\
\hline 18 & Trousers & Șòkòtò & L L L & $\mathrm{LM}$ & $\mathrm{L} \mathrm{H} \mathrm{H}$ & L L L \\
\hline 19 & Aeroplane & Ọkọ̀ òfúrufú & $\begin{array}{l}\text { M L. L H M } \\
\mathrm{H}\end{array}$ & L M & L H. L H H H & Unanswered \\
\hline 20 & Brother & Egbọ́n & $\mathrm{LH}$ & $\mathrm{M}$ & $\mathrm{LH}$ & $\mathrm{LH}$ \\
\hline 21 & School & Ilé-ẹ̀kọ́ & M H. L H & $\mathrm{M}$ & L H. H H & M H L H \\
\hline 22 & Slate & Síléètì & H H L L & $\mathrm{L} M / \mathrm{M}$ & $\mathrm{LH} \mathrm{H}$ & H H L \\
\hline 23 & Calabash & Igbá & M H & $\mathrm{M} / \mathrm{L}$ & $\mathrm{LH}$ & $\mathrm{MH}$ \\
\hline 24 & Cat & Olóngbò & M H L & $\mathrm{L} / \mathrm{M}$ & $\mathrm{LH} \mathrm{H}$ & M H L \\
\hline 25 & Charcoal & Ėédú & $\mathrm{LH} \mathrm{H}$ & L L & $\mathrm{H} \mathrm{H}$ & Unanswered \\
\hline 26 & Chief & Olóyè & M H L & M M & $\mathrm{LHH}$ & M H L \\
\hline 27 & Dance & Jó & $\mathrm{H}$ & $\mathrm{M}$ & $\mathrm{H}$ & $\mathrm{H}$ \\
\hline 28 & Day & Ojộ & M H & L M & $\mathrm{H} \mathrm{H}$ & M H \\
\hline 29 & Divide & Pín & $\mathrm{H}$ & $\mathrm{M} / \mathrm{L}$ & $\mathrm{H}$ & $\mathrm{HH}$ \\
\hline 30 & Eighteen & Méjìdínlógún & H L H H H & $\mathrm{L}$ & H L H H H & Unanswered \\
\hline 31 & Faeces & İgbẹ & $\mathrm{LH}$ & $\mathrm{M}$ & $\mathrm{LH}$ & $\mathrm{LH}$ \\
\hline 32 & Firewood & Igi ìdáná & M M. LH H & L M & & Unanswered \\
\hline 33 & Forget & Gbàgbé & $\mathrm{LH}$ & L M & $\mathrm{H} \mathrm{H}$ & L H \\
\hline 34 & Goat & Eran & M M & L M & $\mathrm{LH} \mathrm{H}$ & $\mathrm{MH}$ \\
\hline 35 & Guinea fowl & Eyẹelé & M M H & $\mathrm{L} M / \mathrm{M}$ & $\mathrm{LH} \mathrm{H}$ & L L H \\
\hline
\end{tabular}




\begin{tabular}{|c|c|c|c|c|c|c|}
\hline $\mathrm{S} / \mathrm{N}$ & English word & $\begin{array}{c}\text { Yoruba } \\
\text { translation }\end{array}$ & Tone & $\begin{array}{l}\text { A.B tone } \\
\text { perceived }\end{array}$ & $\begin{array}{l}\text { C.D tone } \\
\text { perceived }\end{array}$ & $\begin{array}{c}\text { E.F tone } \\
\text { perceived }\end{array}$ \\
\hline 36 & $\begin{array}{l}\text { Grinding } \\
\text { stone }\end{array}$ & Òkúta İlọta & $\begin{array}{l}\text { L H M. L M } \\
\text { M }\end{array}$ & $\mathrm{LM} / \mathrm{M}$ & LHH.H H H & Unanswered \\
\hline 37 & Head & Orí & M H & M & LH & MH \\
\hline 38 & Hold & $\mathrm{Mu}$ & M & M & M & M \\
\hline 39 & House & Ilé & $\mathrm{MH}$ & L M & LH & M H \\
\hline 40 & Kolanut & Obì & M L & L M & $\mathrm{LH}$ & $\mathrm{LH}$ \\
\hline 41 & Lizard & Aláǹgbá & M HLH & LM & L H H & Unanswered \\
\hline 42 & Masquerade & Eégún & $\mathrm{HH}$ & M & LH & $\mathrm{LH}$ \\
\hline 43 & Monkey & Ộbọ & LM & M & $\mathrm{LH}$ & L M \\
\hline 44 & Nail & İso & LM & $\mathrm{M}$ & $\mathrm{LH}$ & LH \\
\hline 45 & Neck & Ọrùn & M L & $M$ & LH & M L \\
\hline 46 & Nine & Mẹ́sàn-án & $\mathrm{HLH}$ & L/M & $\mathrm{HH}$ & Unanswered \\
\hline 47 & Okra & Ilá & M H & $\mathrm{M} / \mathrm{L}$ & L H & $\mathrm{MH}$ \\
\hline 48 & Orange & Ọsàn & M L & $\mathrm{M} / \mathrm{L}$ & LH & M L \\
\hline 49 & Palm wine & Emu & M M & M & $\mathrm{HH}$ & $\mathrm{HH}$ \\
\hline 50 & Pound & Gún & $\mathrm{H}$ & $\mathrm{M}$ & $\mathrm{H}$ & $\mathrm{H}$ \\
\hline 51 & Rain & Òjò & L L & $\mathrm{L}$ & $\mathrm{LH}$ & L L \\
\hline 52 & Saliva & Itọ́ & M H & M & LH & M H \\
\hline 53 & Sand & Iyẹ̀pè & MLL & L M & $\mathrm{LHH}$ & M L L \\
\hline 54 & Salt & Iyọ̀ & M L & M & LH & M L \\
\hline 55 & Say & Sọ & M & M & $\mathrm{H}$ & Unanswered \\
\hline 56 & See & Rí & $\mathrm{H}$ & M & $\mathrm{HH}$ & $\mathrm{H}$ \\
\hline 57 & Seventy & Ààdórin & & Unanswered & $\mathrm{LHH}$ & Unanswered \\
\hline 58 & Shoe & Bàtà & L L & L M & $\mathrm{HH}$ & L L \\
\hline 59 & Short & Kúrú & $\mathrm{HH}$ & M & $\mathrm{H} \mathrm{H}$ & Unanswered \\
\hline 60 & Small & Kékeré & $\mathrm{HMH}$ & M M & $\mathrm{H} \mathrm{H} \mathrm{H}$ & Unanswered \\
\hline 61 & Smell & Rùn & $\mathrm{L}$ & $\mathrm{L}$ & $\mathrm{H}$ & Unanswered \\
\hline 62 & Sing & Kọrin & M M & M & $\mathrm{H} \mathrm{H}$ & Unanswered \\
\hline 63 & Six & Mẹ́fà & $\mathrm{HL}$ & LM & $\mathrm{H} \mathrm{H}$ & H L \\
\hline 64 & Sit & Jókòó & $\mathrm{HLH}$ & L M/M & $\mathrm{H} \mathrm{H}$ & H L \\
\hline 65 & Stomach & Ikùn & M L & M & M H & Unanswered \\
\hline 66 & Swallow & Gbémì & $\mathrm{HL}$ & M & $\mathrm{HH}$ & $\mathrm{HL}$ \\
\hline 67 & Steal & Jígbé & $\mathrm{HH}$ & $\mathrm{M} / \mathrm{L}$ & $\mathrm{H}$ & $\mathrm{H}$ \\
\hline 68 & Thief & Olè & M L & $\mathrm{L}$ & L H & M L \\
\hline 69 & Toad & Ọ̀pọ̀lọ́ & L L H & LM & L H H & L L H \\
\hline 70 & Tortoise & İjàpá & L L H & M & L L H & L L H \\
\hline 71 & Town & Î̀lú & $\mathrm{LH}$ & M & L L & L H \\
\hline 72 & Tree & Igi & M M & $M / L$ & $\mathrm{LH}$ & Unanswered \\
\hline 73 & Vagina & Obò & M L & $\mathrm{L}$ & L L & L L \\
\hline 74 & Village & Abúlé & $\mathrm{MHH}$ & L M & L L H & Unanswered \\
\hline 75 & Urinate & Tò & $\mathrm{L}$ & $\mathrm{L}$ & $\mathrm{L}$ & $\mathrm{H}$ \\
\hline 76 & Vomit & Bì & $\mathrm{L}$ & $\mathrm{L}$ & $\mathrm{L}$ & $\mathrm{H}$ \\
\hline 77 & War & Ogun & M M & M M & L H & Unanswered \\
\hline 78 & Water & Omi & M M & M & LH & $\mathrm{MH}$ \\
\hline 79 & Well & Kànga & L M & $\mathrm{L}$ & L M & Unanswered \\
\hline 80 & Walk & Rìn & $\mathrm{L}$ & $\mathrm{L}$ & $\mathrm{L}$ & $\mathrm{H} \mathrm{M}$ \\
\hline 81 & Buttocks & Ìdí & $\mathrm{LH}$ & L M/ M & LH & L H \\
\hline 82 & Burn & Jo & $\mathrm{H}$ & M & $\mathrm{H}$ & Unanswered \\
\hline 83 & Dirty & Dòtí & $\mathrm{LH}$ & L M/ M & LH & L H \\
\hline 84 & Dog & Ajá & M H & M & LH & M H \\
\hline 85 & Donkey & Ketekete & M M M M & Unanswered & L L L L & Unanswered \\
\hline
\end{tabular}




\begin{tabular}{|l|l|l|l|l|l|l|}
\hline S/N & English word & \multicolumn{1}{|c|}{$\begin{array}{c}\text { Yoruba } \\
\text { translation }\end{array}$} & \multicolumn{1}{|c|}{ Tone } & \multicolumn{1}{|c|}{$\begin{array}{c}\text { A.B tone } \\
\text { perceived }\end{array}$} & \multicolumn{1}{c|}{$\begin{array}{c}\text { C.D tone } \\
\text { perceived }\end{array}$} & \multicolumn{1}{|c|}{$\begin{array}{c}\text { E.F tone } \\
\text { perceived }\end{array}$} \\
\hline 86 & Dream & Àlá & L H & M & L H & M H \\
\hline 87 & Fish & Eja & M M & M/L & H H & L M \\
\hline 88 & Fruit & Èsọ́ & L M & L & H H & L M \\
\hline 89 & Left & Osì & M L & L M & M H & Unanswered \\
\hline 90 & Heavy & Wúwo & H M & M & H L & M M \\
\hline 91 & Success & Àseyorí & L M M H & L M/ M & L H L H & L H M H \\
\hline
\end{tabular}

Based on the findings tabulated in Table 1, the study established the following about the CVAaphasics A.B; C.D; and E.F. The discussions are captured according to the research objectives.

Perceptual ability of Yoruba tone by CVA-aphasics A.B., C.D. and E.F. The study established that the CVA-aphasic identified as A.B did not perceive a high tone during the perceptual analysis. He gave 'either... or answers'. He was indecisive. When he was re-asked what tone, he could perceive when the audio recording was played again, he heard a tone different from the initial one he perceived, as seen in examples (1) and (2) in Table 1 above. This showed that he had receptive aphasia of the $\mathrm{H}$ tone. According to [7], receptive aphasics may be fluent, aware of the voices around them and able to see the print around but have difficulties making sense of what they hear or the printed word. In the case of A.B, he could hear the tone but would confuse it. Regarding regions of the brain affected, it is evident that A.B's failure to perceive $\mathrm{H}$ tone has to do with his H-tone erasure or unclear storage in his Wernicke's area.

The only tone perceived accurately were the tones evident in mono-syllabic words, except mono-syllabic words with a high tone. This is illustrated in Table 2 below.
Table 2 - Tone perceptual ability of aphasic A.B in mono-syllabic words

\begin{tabular}{|l|l|l|l|l|}
\hline No & $\begin{array}{c}\text { English } \\
\text { word }\end{array}$ & \multicolumn{1}{|c|}{$\begin{array}{c}\text { Yoruba } \\
\text { translation }\end{array}$} & Tone & \multicolumn{1}{|c|}{$\begin{array}{c}\text { A.B tone } \\
\text { perceived }\end{array}$} \\
\hline 1 & Buy & Rà & rà (L) & (L) \\
\hline 2 & Hold & Mu & $\begin{array}{l}\text { mu } \\
\text { (M) }\end{array}$ & (M) \\
\hline 3 & Say & Sọ & $\begin{array}{l}\text { sọ } \\
\text { (M) }\end{array}$ & M \\
\hline 4 & See & Rí & rí (H) & (M) \\
\hline 5 & Dance & Jó & jó (H) & (M) \\
\hline
\end{tabular}

As Table 2 (1)-(3) indicates, Subject A.B. perceived tone accurately in mono-syllabic words with $\mathrm{M}$ and $\mathrm{L}$ tones. However, when presented with mono-syllabic words with $\mathrm{H}$ tone, A.B. would fail to perceive it as $\mathrm{H}$ tone but as $\mathrm{M}$ tone shown in Table 2 (4) and (5). This confirms H-tone and Mtone complications in the cortical or subcortical language receptive areas of his brain.

In di-syllabic words, it was established that CVAaphasic identified as Subject A.B. perceived just a single tone while in words with more than two syllables, he perceived just two tones and, at rare times, a single tone. This is illustrated in Table 3 below.

Table 3 - Tone perceptual ability of aphasic A.B in di-syllabic words

\begin{tabular}{|c|c|c|c|c|}
\hline No & English word & Yoruba translation & Tone & A.B tone perceived \\
\hline 1 & Penis & okọ́ & okọ́ (M H) & (M) \\
\hline 2 & Hunter & odẹ & ode (M M) & (M) \\
\hline 3 & Fool & ọ̀dè & ọ̀dẹ (L L) & (L) \\
\hline 4 & Syllable & sílábù & sílábù (H H L) & (LM) \\
\hline 5 & Bolanle & bóláńlé & bóláńlé (H H H H) & $(\mathrm{LM})$ \\
\hline 6 & Describe & sàlàyé & sàlàyé (L L H) & $(\mathrm{LM} / \mathrm{M})$ \\
\hline 7 & Slate & síléètì & síléètì (H H L L) & $(\mathrm{L} \mathrm{M} / \mathrm{M})$ \\
\hline
\end{tabular}

Table 3 presents the perceptual ability of CVAaphasic A.B. vis-à-vis tone in di-syllabic words. As can be seen in Table 3 (1)-(3), in cases where A.B. was presented with words containing more than one syllable, A.B. always perceived a single tone.
As a result, the CVA-aphasic resorted to using the $\mathrm{M}$ tone for di-syllabic words that blend $\mathrm{M}$ and $\mathrm{H}$. This was similar to his tendency to substitute the $\mathrm{H}$ tone with the $\mathrm{M}$ tone in mono-syllabic words, as earlier observed in Table 2 (4) and (5). We wish to 
argue that the demotion in $\mathrm{H}$ tone to $\mathrm{L}$ tone could result from two possibilities. Firstly, such cases could be attributed to less involvement in articulating $\mathrm{L}$ tones than $\mathrm{H}$ tones after a stroke since $\mathrm{H}$ tones involve more energy and muscular involvement than L tones. Secondly, it could also be that Subject A.B has targeted lexical erasure in his Wernicke's area and thereby exhibiting receptive aphasia or Wernicke's aphasia to the H-tone and M tones.

For words with more than two syllables, A.B. just perceived two tones and, at rare times, a single tone as seen in Table 3 (4) and (5) and Table 3 (6) and (7), respectively. We think such a tendency is due to either extra muscular involvement and energy associated with words that have more than two syllables (hence CVA-aphasics would instead reduce such to two syllables only) or possible erasure in the subject's language receptive regions of his brain [7]. From their articulations, it is also possible that A.B's Wernicke's area is probably intact. Still, the production of what he already knows (linguistic competence area) is hampered by limitations of the scale of damage to Broca's area (linguistic performance area). In any case, linguistic therapies towards A.B would include focusing more on $\mathrm{H}$ tone production and help him extend his energies towards more syllables in disyllabic and words with more than two syllables.

Concerning CVA-aphasic identified as C.D, it was observed that he articulated some tones correctly (e.g. see word item 1, 5, 20, 27, 29 and 31 in Table 1). However, there were instances whereby C.D substituted the $\mathrm{M}$ tone for the $\mathrm{L}$ tone; substituted the $\mathrm{M}$ tone for the $\mathrm{H}$ tone; and instances where he substituted the $\mathrm{L}$ tone for the $\mathrm{H}$ tone. This is shown in Table 4, Table 5 and Table 6 below.

Table 4 - C.D's substitution of mid (M) tone for low (L) tone

\begin{tabular}{|l|l|l|l|l|}
\hline No & $\begin{array}{c}\text { English } \\
\text { word }\end{array}$ & $\begin{array}{c}\text { Yoruba } \\
\text { translation }\end{array}$ & \multicolumn{1}{|c|}{ Tone } & $\begin{array}{l}\text { C.D tone } \\
\text { perceived }\end{array}$ \\
\hline 1 & Kolanut & Obì & obì (M L) & (L H) \\
\hline 2 & Lizard & Alángbá & $\begin{array}{l}\text { alángbá } \\
\text { (M H L H) }\end{array}$ & (L H H) \\
\hline 3 & House & Ilé & ilé (M H) & (L H) \\
\hline 4 & Neck & Orùn & $\begin{array}{l}\text { orùn (M } \\
\text { L) }\end{array}$ & (L H) \\
\hline 5 & Okra & Ilá & ilá (M H) & (L H) \\
\hline 6 & Saliva & Itọ́ & itọ́ (M H) & (L H) \\
\hline 7 & Sand & Iyẹ̀pè̀ & $\begin{array}{l}\text { iyẹ̀pẹ̀ (M L } \\
\text { L) }\end{array}$ & (L H H) \\
\hline
\end{tabular}

Table 4 demonstrates how C.D substituted the M tone for the $\mathrm{L}$ tone. In this respect, C.D displayed a similar yet different tone perception to Subject A.B. While A.B and C.D both interpreted some tone differently, C.D generally substituted $M$ tone for the L tone, as shown in Table 4. In contrast, C.D generally interpreted $\mathrm{H}$ tone as $\mathrm{M}$ tone as illustrated in Table 2 (4) and (5) above, albeit in monosyllabic words.

C.D also substituted the $\mathrm{M}$ tone for the $\mathrm{H}$ tone, as shown in Table 5 below.

Table 5 - C.D's substitution of mid (M) tone for high (H) tone

\begin{tabular}{|l|l|l|l|l|}
\hline No & $\begin{array}{c}\text { English } \\
\text { word }\end{array}$ & $\begin{array}{c}\text { Yoruba } \\
\text { translation }\end{array}$ & Tone & $\begin{array}{c}\text { C.D tone } \\
\text { perceived }\end{array}$ \\
\hline 1 & Disappear & parẹ́ & $\begin{array}{l}\text { parẹ́ (M } \\
\text { H) }\end{array}$ \\
\hline 2 & Day H $)$ & jajọ́ & $\begin{array}{l}\text { ojọ́ } \\
\text { H) }\end{array}$ \\
\hline 3 & Palm wine & Emu H $)$ & $\begin{array}{l}\text { emu (M } \\
\text { M) }\end{array}$ & (H H) \\
\hline
\end{tabular}

Table 5 demonstrates C.D's tendency to substitute the $\mathrm{M}$ tone for the $\mathrm{H}$ tone. This is a unique situation from Subject A.B, who could not articulate the $\mathrm{H}$ tone in most words but substitute it with the $\mathrm{L}$ tone. This finding provides proof of the varying perceptual tendencies among CVA-insults among aphasics. Two individuals may not display identical weaknesses. This is because aphasic insults may affect different brain areas, leading to differential inabilities and recovery trajectories, as alluded to above.

A further exciting finding of C.D was that, for some words, he would substitute the $\mathrm{L}$ tone for the $\mathrm{H}$ tone. It can be observed that C.D is very inconsistent in tone perception. The substitution of $\mathrm{L}$ tone for $\mathrm{H}$ tone is illustrated in Table 6 below.

Table 6 - C.D's substitution of low $(\mathrm{L})$ tone for high $(\mathrm{H})$ tone

\begin{tabular}{|c|c|c|c|c|}
\hline No & $\begin{array}{l}\text { English } \\
\text { word }\end{array}$ & $\begin{array}{c}\text { Yoruba } \\
\text { translation }\end{array}$ & Tone & $\begin{array}{l}\text { C.D tone } \\
\text { perceived }\end{array}$ \\
\hline 1 & Forget & Gbàgbé & $\begin{array}{l}\text { gbàgbé } \\
(\mathrm{L} \mathrm{H})\end{array}$ & $(\mathrm{H} \mathrm{H})$ \\
\hline 2 & Shoe & Bàtà & \begin{tabular}{|l|l} 
bàtà & $(\mathrm{L}$ \\
$\mathrm{L})$
\end{tabular} & $(\mathrm{H} \mathrm{H})$ \\
\hline 3 & stand & dìde & \begin{tabular}{|ll} 
dìde & (L \\
M)
\end{tabular} & $(\mathrm{H} \mathrm{L})$ \\
\hline
\end{tabular}


Table 6 confirms that for every L tone, C.D perceives it as an $\mathrm{H}$ tone, and for every $\mathrm{M}$ tone, it is interpreted as an L tone as earlier alluded to in Table 4 or as $\mathrm{H}$ tone as shown in Table 5 . Unfortunately, due to ethical reasons, the researchers could not ask medical experts who handled the clients what caused such inconsistencies, as shown by C.D. It is, however, hoped that the finding of C.D will open further research into the dynamics of tone perception among CVA-triggered aphasics and the neurological and non-neurological factors that cause such.

Unlike Subjects A.B and C.D, subject E.F perceived a lot of tones correctly (e.g., see Table 1, word items 5-10; 18, 23, 24, 26, 28, 31, 33, 37, 39, 43, 45, 47, 48, 66; 67-71; 81, 83, 84). However, E.F manifested several instances whereby he found it difficult to perceive the tones in some words, and the researchers tagged these instances were tagged as 'unanswered'. Examples of unanswered word items are tabulated in Table 7 below.

Table 7 - E.F's unanswered word items

\begin{tabular}{|l|l|l|l|l|}
\hline No & $\begin{array}{l}\text { English } \\
\text { word }\end{array}$ & $\begin{array}{l}\text { Yoruba } \\
\text { translation }\end{array}$ & \multicolumn{1}{|c|}{ Tone } & \multicolumn{1}{|c|}{$\begin{array}{c}\text { E.F tone } \\
\text { perceived }\end{array}$} \\
\hline 1 & Rat & eku & $\begin{array}{l}\text { eku (M } \\
\text { M) }\end{array}$ & Unanswered \\
\hline 2 & Bolanle & Bóláńlé & $\begin{array}{l}\text { bóláńlé } \\
\text { (H H H } \\
\text { H) }\end{array}$ & Unanswered \\
\hline 3 & Hunter & ọdẹ & $\begin{array}{l}\text { oddẹ (M } \\
\text { M) }\end{array}$ & Unanswered \\
\hline 4 & Fool & òdè & $\begin{array}{l}\text { òdẹ̀ (L L) } \\
\text { èédú (L L } \\
\text { H H) }\end{array}$ & Unanswered \\
\hline 5 & Charcoal & Ėédú & $\begin{array}{l}\text { kúrú (H } \\
\text { H) }\end{array}$ & Unanswered \\
\hline 6 & Short & Kúrú & $\begin{array}{l}\text { kékeré } \\
\text { (H M H) }\end{array}$ & Unanswered \\
\hline 7 & Small & kékeré & \multicolumn{2}{|l}{} \\
\hline
\end{tabular}

Table 7 presents a unique finding regarding E.F. Although E.F could answer most questions correctly with the right tone than both A.B and C.D combined (see Table 1 above), he also had a lot of questions tagged 'Unanswered'. E.F is unique because, on the one hand, he gave the correct tone to most words but, on the other hand, could not articulate some words altogether. Could it be that his language perception centre has some erasure of some words? We cannot attribute such selective abilities to transcortical sensory aphasia or transcortical motor aphasia because it was evident that E.F had no significant problems with the language command network between the Broca's area and the Wernicke's area. With further permission, we are sure future research can look at cases like those related to E.F and provide valuable insights to such's language centres.

Tone competence among Yoruba-speaking aphasic adults. This study revealed that tone differentiation is possible among Yoruba-speaking aphasic adults but with varying competence in differentiation. For example, subject E.F responded to most word items compared to Subjects A.B and C.D (see Table 1 above). On the other hand, although Subject C.D got some tones correct, he also gave the most inconsistent tone patterns compared to Subjects A.B and E.F. Additionally, although A.B managed to differentiate some tones in some words; he could not even respond to some word items just like Subject E.F.

The findings on differential tone competence confirmed studies in clinical linguistics that have established that aphasics recover differently depending on the duration of the CVA-triggered aphasic insult [7]. Due to their ability to still perceive some tones correctly, it is evident that A.B, C.D and E.F have temporal or transient aphasia instead of permanent aphasia, which reflects more extraordinary incompetence due to the more extended period taken to recover. Regarding tone aspects affected by the CVA, the fact that A.B, C.D and E.F can express themselves with little difficulty entails that their medical condition of expressive aphasia is not bad. However, that Subjects A.B and E.F could not reply to some word items provided to them is an indication that they have some minor prevalence of receptive aphasia. In other words, the inability of A.B and E.F to provide tone to some word items provides possibilities of lexical erasure in their Wernicke's area [7, 18].

Most perceptually challenging lexical tones. During data collection from subject A.B, C.D and E.F words with similar letters which are distinguished by tones (e.g., see Table 1, word items 810 and 14-15 such as oko 'farm'; okọ̀ 'vehicle'; okó 'penis'; ọde 'hunter'; and ọ̀dè 'fool') threw the subjects in a state of confusion as they had difficulty identifying the tones evident in those words, even though the audio was played several times. Though, unlike A.B and C.D, Subject E.F perceived the tones of 8-10 correctly, all the subjects perceived the tones of the words in 14-15 wrongly.

Based on the findings, it can be deduced that words written the same but pronounced 
differently (homographs) posed the most significant challenge to A.B, C.D and E.F regardless of their varying and diverse tonological competence.

\section{CONCLUSIONS}

This study looked at tone usage among Yorubaspeaking CVA-aphasic adults from the autosegmental approach to phonology. It did this by focusing on the subsequent research questions: do Yoruba-speaking aphasic adults have the perceptual ability to perceive tones in the language; can Yoruba-speaking aphasic adults differentiate between the three lexical tones in the language; and which of lexical tones do Yoruba speaking aphasic adults find difficult to perceive? The findings have revealed that aphasics display different abilities on tone depending on factors such as severity, duration and parts of the brain affected by the aphasic insult. This finding confirms other researches already done on aphasia, as alluded to by [7]. In terms of literature review, the current enquiry adds more knowledge to earlier studies on aphasia such as that of [23], who explored the role of inflectional morphology in agrammatism; [23], who conducted a phonological analysis in the speech of Nigerian bilingual adults; and [16] who examined the pronominal production resumption, focus constructions (who-questions) and focused declarative in Akan. The significant implications of the current study are that language therapists and speech pathologists need to contextualise each aphasic case since no two aphasics may necessarily reflect identical recovery patterns and tonal competence after CVAtriggered aphasia.

\section{REFERENCES}

1. Bastiaanse, R., \& Platonov, A. (2014). Argument Structure and Time Reference in Agrammatic Aphasia. Cognitive Science Perspectives on Verb Representation and Processing, 141-155. doi: 10.1007/978-3-319-10112-5_7

2. Bleser, R., \& Bayer, J. (1988). On the role of Inflectional Morphology in Agrammatism. Retrieved from http://kops.unikonstanz.de/bitstream/handle/123456789/3795/On_the_Role_of_Inflectional_Morphology_in_ Agrammatism.pdf; sequence $=1$

3. Blesser \& Poeck (1983). Comments on "Neurolinguistics analysis of recurring utterance in aphasia" by C. Code. Cortex, 19, 259-260.

4. Brink, J. B., \& Wood, M. J. (1998). Advanced Designs in Nursing Research (2nd ed.). London: Sage.

5. Code, C. (1982). Neurolinguistic Analysis of Recurrent Utterance in Aphasia. Cortex, 18(1), 141-152. doi: 10.1016/s0010-9452(82)80025-7

6. Creswell, J. W., \& Creswell, J. D. (2013). Research Design: Qualitative, Quantitative and Mixed Methods Approaches. Thousand Oaks: Sage Publications.

7. Crystal, D. (1991). A Dictionary of Linguistics and Phonetics. Malden: Blackwell Publishing.

8. Cummings, L. (Ed.). (2013). The Cambridge Handbook of Communication Disorders. doi: $10.1017 /$ cbo9781139108683

9. Descartes, R. (1637). Discourse on the method of rightly conducting one's reason and of seeking truth in the sciences. N. d.: n. d.

10. Goldstein, K. (1971). Language and language disturbances aphasic symptom complexes and their significance for medicine and theory of language. New York: Grune\&Stratton.

11. Green, E. (1969). Phonological and Grammatical Aspects of Jargon in an Aphasic Patient: a Case Study. Language and Speech, 12(2), 103-118. doi: 10.1177/002383096901200203

12. Groenewold, R., Bastiaanse, R., Nickels, L., Wieling, M., \& Huiskes, M. (2014). The differential effects of direct and indirect speech on discourse comprehension in Dutch and English listeners with and without aphasia. Aphasiology, 29(6), 685-704. doi: 10.1080/02687038.2014.977217

13. Kiparsky, P. (1982). Lexical morphology and phonology. Cambridge: M.I.T. 
14. Kumar, A. (2014). Research methodology: A step by step guide for beginners. London: ISAGE Publications Ltd.

15. Lapointe, S. G. (1985). A theory of verb form use in the speech of agrammatic aphasics. Brain and Language, 24(1), 100-155. doi: 10.1016/0093-934x(85)90100-2

16. Lartey, N., \& Bastiaanse, R. (2018). The processing of pronominal resumption in Akan agrammatic speakers: An interplay between syntax and phonology. Frontiers in Human Neuroscience, 12. doi: 10.3389/conf.fnhum.2018.228.00044

17. Mafofo, L., \& Banda, F. (2014). Accentuating institutional brands: A multimodal analysis of the homepages of selected South African universities. Southern African Linguistics and Applied Language Studies, 32(4), 417-432. doi: 10.2989/16073614.2014.997068

18. Malmkjaer, K. (1991). The Linguistics Encyclopedia. London: Routledge.

19. Matchin, W., \& Rogalsky, C. (2020). Aphasia and Syntax. doi: 10.31234/osf.io/m8pnd

20. Paradis, M. (2004). A Neurolinguistic Theory of Bilingualism. Amsterdam: John Benjamins.

21. Prathiba, K. (1989). Aphasia Rehabilitation in India. Retrieved from https://www.academia.edu/5448833/Aphasia_Rehabilitation_in_India_by_Prathibha_Karanth

22. Siriboonpipattana, W., Nickels, L., \& Bastiaanse, R. (2020). An investigation of time reference in production and comprehension in Thai speakers with agrammatic aphasia. Aphasiology, 35(9), 1168-1189. doi: 10.1080/02687038.2020.1781777

23. Sunday, A. B. (2013). The Segmentals of Bilingual Nigerian Adult Broca's Aphasics. International Journal of Applied Linguistics \& English Literature, 2(3), 83-94. doi: 10.7575/aiac.ijalel.v.2n.3p.83

24. Thompson, C. K. (2019). Neurocognitive Recovery of Sentence Processing in Aphasia. Journal of Speech, Language, and Hearing Research, 62(11), 3947-3972. doi: 10.1044/2019_jslhr-l-rsnp19-0219

25. Thompson, C. K., \& Choy, J. J. (2009). Pronominal Resolution and Gap Filling in Agrammatic Aphasia: Evidence from Eye Movements. Journal of Psycholinguistic Research, 38(3), 255-283. doi: 10.1007/s10936-009-9105-7

26. Thompson, C., \& Shapiro, L. (2005). Treating agrammatic aphasia within a linguistic framework: Treatment of Underlying Forms. Aphasiology, 19(10-11), 1021-1036. doi: $10.1080 / 02687030544000227$ 